\title{
CORRECTION
}

\section{Rise of women in medicine not matched by leadership roles}

CMAJ has been made aware of an error that appeared in the news article "Rise of women in medicine not matched by leadership roles," published in the Apr. 16, 2018 , issue. ${ }^{1}$ The article reported that "Today, $63 \%$ of Canadian medical students are women." According to the Association of Faculties of Medicine of Canada, the actual percentage of female Canadian medical students is $56 \%{ }^{2}$

- Cite as: CMAJ 2018 August 7;190:E942. doi: 10.1503/cmaj.180959

\section{References}

1. Glauser W. Rise of women in medicine not matched by leadership roles. CMAJ 2018;190: E479-80.

2. Canadian medical education statistics. Vol. 39 . Ottawa: Association of Faculties of Medicine of Canada (AFMC); 2017. Available: https://afmc.ca/sites/ default/files/CMES2017-Complete.pdf (accessed 2018 July 24). 